\title{
Zinc(II) and Nickel(II) Benzoate Complexes from the Use of 1-methyl-4,5-diphenylimidazole
}

\author{
Konstantina A. Kounavi, ${ }^{1}$ Manolis J. Manos, ${ }^{2}$ Anastasios J. Tasiopoulos, ${ }^{2}$ \\ Spyros P. Perlepes, ${ }^{1}$ and Vassilios Nastopoulos ${ }^{1}$
}

${ }^{1}$ Department of Chemistry, University of Patras, 26504 Patras, Greece
${ }^{2}$ Department of Chemistry, University of Cyprus, 1678 Nicosia, Cyprus

Correspondence should be addressed to Vassilios Nastopoulos, nastopoulos@chemistry.upatras.gr

Received 3 April 2010; Accepted 14 May 2010

Academic Editor: Evy Manessi-Zoupa

Copyright (C) 2010 Konstantina A. Kounavi et al. This is an open access article distributed under the Creative Commons Attribution License, which permits unrestricted use, distribution, and reproduction in any medium, provided the original work is properly cited.

\begin{abstract}
Two new complexes, $\left[\mathrm{Zn}\left(\mathrm{O}_{2} \mathrm{CPh}\right)_{2}(\mathrm{~L})_{2}\right] \cdot 2 \mathrm{MeOH}(\mathbf{1} \cdot 2 \mathrm{MeOH})$ and $\left.\left[\mathrm{Ni}_{2}\left(\mathrm{O}_{2} \mathrm{CPh}\right)\right)_{4}(\mathrm{~L})_{2}\right] \cdot 2 \mathrm{MeCN}(\mathbf{2} \cdot 2 \mathrm{MeCN})$, have been synthesized and characterized by X-ray analysis in the course of an ongoing investigation of the $\mathrm{M}^{\mathrm{II}} / \mathrm{X}^{-} / \mathrm{L}\left[\mathrm{M}^{\mathrm{II}}=\mathrm{Co}, \mathrm{Ni}, \mathrm{Cu}, \mathrm{Zn}\right.$; $\mathrm{X}^{-}=\mathrm{Cl}^{-}, \mathrm{Br}^{-}, \mathrm{I}^{-}, \mathrm{NCS}^{-}, \mathrm{NO}_{3}^{-}, \mathrm{N}_{3}{ }^{-}, \mathrm{PhCO}_{2}^{-} ; \mathrm{L}=1$-methyl-4,5-diphenylimidazole] reaction system, aiming at understanding and assessing the relative strength and the way in which the intermolecular interactions control the supramolecular organization of these compounds. In the mononuclear complex $1 \cdot 2 \mathrm{MeOH}$, the benzoate ion acts as a monodentate ligand resulting in a distorted tetrahedral $\mathrm{N}_{2} \mathrm{O}_{2}$ coordination environment. Complex $2 \cdot 2 \mathrm{MeCN}$ exhibits a dinuclear paddle-wheel structure; each $\mathrm{Ni}^{\mathrm{II}}$ has a square pyramidal $\mathrm{NiNO}_{4}$ chromophore with four benzoate oxygens in the basal plane and the pyridine-type nitrogen atom of one ligand $\mathrm{L}$ at the apex. The structure of $1 \cdot 2 \mathrm{MeOH}$ is stabilized by intramolecular $\pi-\pi$ interactions between aromatic rings of adjacent 4,5-diphenylimidazole moieties; it is a feature also evidenced in similar compounds of the type $\left[\mathrm{MX}_{2} \mathrm{~L}_{2}\right]$.
\end{abstract}

\section{Introduction}

Imidazole and its derivatives have played a formative role in the development of coordination chemistry $[1,2]$. Many hundreds of neutral complexes and complex ions containing imidazoles have been prepared and characterized. The variety of spectroscopic properties and stoichiometries observed led to an improved understanding of the geometry and bonding in complexes and provided a touchstone for bonding theories. Imidazoles are particularly interesting ligands in bioinorganic $[3,4]$ and metallosupramolecular [5] chemistry. In the former field, imidazoles mimic the side chain of histidine and are valuable in biological modeling. Metalloenzyme synthetic models target the enzyme active site structure, spectroscopy, and mechanism of action. Further, bioinorganic models may also lead to compounds which mimic enzyme function and provide new reagents or catalysts for practical application. In the latter field, the presence of both donor atoms to metal ions and hydrogen bond donors within imidazoles, combined with the $\pi$-excessive character of the 5-membered heterocyclic ring, can lead to intermolecular assembly of metal complexes through ligandligand or ligand-inorganic anion interactions. In spite of the enormous scientific literature on metal complexes with simple imidazoles as ligands, there is in fact relatively little known about the coordination and metallosupramolecular chemistry of heavily substituted imidazoles [1].

It is well established nowadays that the most prominent intermolecular interactions responsible for the supramolecular organization of metal complexes are hydrogen bonds and $\pi-\pi$ stacking interactions [6-11]. With this in mind, an investigation has recently been initiated to determine the crystal structures of a designed series of transition metal complexes using heavily substituted imidazole ligands aiming at understanding the relative strength and the way in which these interactions control the noncovalent assembly of molecular building blocks in supramolecular systems [12]. In particular, 1-methyl-4,5-diphenylimidazole (L) (Scheme 1), a monodentate ligand capable of forming $\pi-\pi$ interactions, has been selected to initiate our studies. So far, there have 


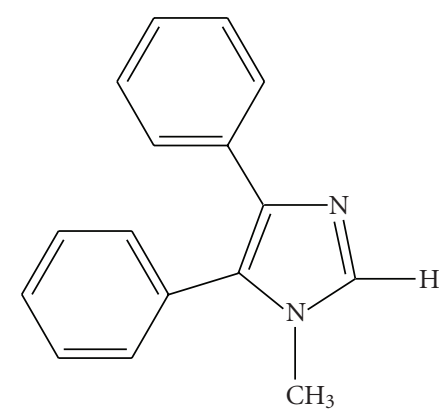

Scheme 1: Drawing of the ligand 1-methyl-4,5-diphenylimidazole.

been only few studies on the coordination chemistry of $\mathrm{L}[13,14]$. The general reaction system currently in use involves $\mathrm{M}^{\mathrm{II}} / \mathrm{X}^{-} / \mathrm{L}^{-}\left[\mathrm{M}^{\mathrm{II}}=\mathrm{Co}, \mathrm{Ni}, \mathrm{Cu}, \mathrm{Zn} ; \mathrm{X}^{-}=\mathrm{Cl}^{-}, \mathrm{Br}^{-}\right.$, $\left.\mathrm{I}^{-}, \mathrm{RCO}_{2}{ }^{-}, \mathrm{NO}_{3}{ }^{-}, \mathrm{NCS}^{-}, \mathrm{N}_{3}{ }^{-}\right]$in various solvents and the first $\mathrm{Co}(\mathrm{II})$ and $\mathrm{Zn}(\mathrm{II})$ complexes have already been reported [12].

In this study we present our results on the $\mathrm{M}^{\mathrm{II}} / \mathrm{PhCO}_{2}{ }^{-} / \mathrm{L}$ $\left[\mathrm{M}^{\mathrm{II}}=\mathrm{Co}, \mathrm{Ni}, \mathrm{Cu}, \mathrm{Zn}\right]$ system. So far, two new complexes, namely, $\left[\mathrm{Zn}\left(\mathrm{O}_{2} \mathrm{CPh}\right)_{2}(\mathrm{~L})_{2}\right] \cdot 2 \mathrm{MeOH}(\mathbf{1} \cdot 2 \mathrm{MeOH})$ and $\left.\left[\mathrm{Ni}_{2}\left(\mathrm{O}_{2} \mathrm{CPh}\right)\right)_{4}(\mathrm{~L})_{2}\right] \cdot 2 \mathrm{MeCN}(\mathbf{2} \cdot 2 \mathrm{MeCN})$ have been synthesized and characterized by elemental analyses, IR spectra, and single-crystal X-ray analysis.

\section{Experimental}

2.1. Materials and Instruments. Chemicals (reagent grade) were purchased from Merck and Alfa Aesar. All manipulations were performed under aerobic conditions using materials and solvents as received; water was distilled inhouse. The ligand 1-methyl-4,5-diphenylimidazole (L) was synthesized as already described in a previous work [15]. Microanalyses $(\mathrm{C}, \mathrm{H}, \mathrm{N})$ were performed by the University of Ioannina (Greece) Microanalytical Laboratory using an EA 1108 Carlo Erba analyzer. IR spectra were recorded on a Perkin-Elmer PC 16 FT-IR spectrometer with samples prepared as $\mathrm{KBr}$ pellets.

\subsection{Compound Preparation}

2.2.1. Preparation of $\left[\mathrm{Zn}\left(\mathrm{O}_{2} \mathrm{CPh}\right)_{2}(\mathrm{~L})_{2}\right] \cdot 2 \mathrm{MeOH}(\mathbf{1} \cdot 2 \mathrm{MeOH})$. This compound was synthesized by a solvothermal reaction of $\mathrm{L}(0.18 \mathrm{~g}, 0.75 \mathrm{mmol})$ and $\mathrm{Zn}\left(\mathrm{O}_{2} \mathrm{CPh}\right)_{2} \cdot 2 \mathrm{H}_{2} \mathrm{O}(0.10 \mathrm{~g}$, $0.30 \mathrm{mmol})$ in $\mathrm{MeOH}(8 \mathrm{~mL})$. The reaction mixture was loaded into a Teflon-lined stainless steel autoclave with inner volume of $20 \mathrm{~mL}$, and then the sealed autoclave was heated under autogenous pressure at $150^{\circ} \mathrm{C}$ for 3 days. Upon slow $\left(5^{\circ} \mathrm{C} / \mathrm{h}\right)$ cooling to ambient temperature, colourless prismatic crystals of $\mathbf{1} \cdot 2 \mathrm{MeOH}$ (suitable for X-ray crystallography) appeared, which were collected by filtration, washed with cold $\mathrm{EtOH}(2 \times 2 \mathrm{~mL})$ and $\mathrm{Et}_{2} \mathrm{O}(2 \times 5 \mathrm{~mL})$, and dried in air; yield ca. $40 \%$ (based on the metal). A sample for crystallography was maintained in contact with the mother liquor to prevent the loss of lattice solvent Anal. Calc. for 1.2MeOH: C, 68.61; H, 5.53; N, 6.67\%. C, 68.30; H, 5.41;
$\mathrm{N}, 6.88 \%$. IR data $\left(\mathrm{KBr}, \mathrm{cm}^{-1}\right): 3446(\mathrm{mb}), 3130(\mathrm{~m}), 3054$ $(\mathrm{m}), 2924(\mathrm{w}), 1624(\mathrm{~s}), 1570(\mathrm{~s}), 1520(\mathrm{~s}), 1484(\mathrm{~m}), 1446$ (m), $1366(\mathrm{~s}), 1256(\mathrm{~m}), 1196(\mathrm{~m}), 1174(\mathrm{w}), 1126(\mathrm{~m}), 1072$ (m), $1024(\mathrm{~m}), 1000(\mathrm{w}), 978(\mathrm{~m}), 920(\mathrm{~m}), 838(\mathrm{~m}), 788(\mathrm{~s})$, $774(\mathrm{~s}), 744(\mathrm{sh}), 720(\mathrm{~s}), 700(\mathrm{~s}), 680(\mathrm{~m}), 650(\mathrm{~m}), 580(\mathrm{~m})$, $512(\mathrm{w})$.

2.2.2. Preparation of $\left.\left[\mathrm{Ni}_{2}\left(\mathrm{O}_{2} \mathrm{CPh}\right)\right)_{4}(\mathrm{~L})_{2}\right] \cdot 2 \mathrm{MeCN}(2 \cdot 2 \mathrm{MeCN})$. A pale yellow solution of $\mathrm{L}(0.29 \mathrm{~g}, 1.25 \mathrm{mmol})$ in $\mathrm{MeCN} / \mathrm{CH}_{2} \mathrm{Cl}_{2}(30 \mathrm{~mL}, 1: 1 \mathrm{v} / \mathrm{v})$ was treated with solid $\mathrm{Ni}\left(\mathrm{O}_{2} \mathrm{CPh}\right)_{2} \cdot 2 \mathrm{H}_{2} \mathrm{O}(0.17 \mathrm{~g}, 0.50 \mathrm{mmol})$. The resulting green slurry was stirred at ambient temperature for $20 \mathrm{~min}$. The solution was filtered and the green filtrate was left undisturbed in a closed vial at room temperature. After 15 days, light-green crystals of $1 \cdot 2 \mathrm{MeCN}$ suitable for X-ray analysis formed were collected by filtration, washed with cold $\mathrm{EtOH}(2 \times 2 \mathrm{~mL})$ and $\mathrm{Et}_{2} \mathrm{O}(2 \times 5 \mathrm{~mL})$, and dried in air. Yield ca. $60 \%$ (based on the metal). A sample for crystallography was maintained in contact with the mother liquor to prevent the loss of lattice solvent. Anal. Calc. for 2.2MeCN: C, 66.69; H, 4.73; N, 7.29\%. Found: C, 66.81; H, 4.40; N, 7.38\%. IR data $\left(\mathrm{KBr}, \mathrm{cm}^{-1}\right): 3134(\mathrm{~m}), 3060(\mathrm{~m}), 1626(\mathrm{~s}), 1570(\mathrm{~s})$, $1522(\mathrm{~s}), 1492(\mathrm{w}), 1444(\mathrm{sh}), 1418(\mathrm{~s}), 1402(\mathrm{~s}), 1254(\mathrm{w})$, $1202(\mathrm{~m}), 1174(\mathrm{w}), 1072(\mathrm{~m}), 1024(\mathrm{~m}), 978(\mathrm{~m}), 922(\mathrm{w})$, $842(\mathrm{w}), 786(\mathrm{~m}), 776(\mathrm{sh}), 720(\mathrm{~s}), 700(\mathrm{~s}), 682(\mathrm{~m}), 648(\mathrm{~m})$, $538(\mathrm{w}), 476(\mathrm{~m})$.

2.3. X-Ray Crystallography. Selected single crystals of $1 \cdot 2 \mathrm{MeOH}$ and $2 \cdot 2 \mathrm{MeCN}$ were covered with Paraton $\mathrm{N}$ oil and mounted on the tip of a glass capillary. X-ray data for both compounds were collected ( $\omega$-scans) on an Oxford Diffraction Xcalibur diffractometer under a flow of nitrogen gas at $100(2) \mathrm{K}$ (MoK $\alpha$ radiation). For data collection and reduction the CrysAlis CCD and RED packages were employed [16], respectively. The reflection intensities were corrected for absorption (multiscan method), the structures were solved by direct methods with SIR92 [17] and refined by full-matrix least-squares on $F^{2}$ with SHELXL-97 [18]. All nonhydrogen atoms were refined anisotropically. All hydrogen atoms bound to carbon atoms were introduced at calculated positions applying the riding model $\left[\mathrm{C}\left(s p^{2}\right)-\right.$ $\mathrm{H}$ and $\mathrm{C}\left(s p^{3}\right)-\mathrm{H} 0.93$ and $0.96 \AA$, respectively; $U_{\text {iso }}(\mathrm{H})=$ $1.2 U_{\mathrm{eq}}(\mathrm{C})$ (1.5 for $\mathrm{Cs} p^{3}$ methyl groups) of their parent $\mathrm{C}$ atom]. The hydroxyl hydrogen atoms of the solvent molecules in $\mathbf{1} \cdot 2 \mathrm{MeOH}$ were located by difference maps and their positions were refined isotropically $\left[U_{\text {iso }}(\mathrm{H})=\right.$ $\left.1.5 U_{\text {eq }}(\mathrm{O})\right]$ applying a soft distance restraint. All geometric calculations were carried out using WINGX [19], PLATON [20], and MERCURY [21] packages; molecular graphics were prepared with DIAMOND [22]. Details of the data collection and refinement are summarized in Table 1.

CCDC-771769 and CCDC-771770 contain the crystallographic data for $\mathbf{1} \cdot 2 \mathrm{MeOH}$ and $2 \cdot 2 \mathrm{MeCN}$, respectively. These data can be obtained free of charge via http://www.ccdc.cam.ac.uk/conts/retrieving.html, or from the Cambridge Crystallographic Data Centre, 12 Union Road, Cambridge CB2 1EZ, UK; fax: (+44) 1223-336-033; or e-mail: deposit@ccdc.cam.ac.uk. 
TABle 1: Crystal data and refinement parameters for complexes $1 \cdot 2 \mathrm{MeOH}$ and $2 \cdot 2 \mathrm{MeCN}$.

\begin{tabular}{|c|c|c|}
\hline & $\mathbf{1} \cdot 2 \mathrm{MeOH}$ & $2 \cdot 2 \mathrm{MeCN}$ \\
\hline Empirical formula & $\mathrm{C}_{48} \mathrm{H}_{46} \mathrm{~N}_{4} \mathrm{O}_{6} \mathrm{Zn}$ & $\mathrm{C}_{64} \mathrm{H}_{54} \mathrm{~N}_{6} \mathrm{O}_{8} \mathrm{Ni}_{2}$ \\
\hline Formula weight $\left(\mathrm{g} \mathrm{mol}^{-1}\right)$ & 840.26 & 1152.55 \\
\hline Temperature & $100(2)$ & $100(2)$ \\
\hline Wavelength & 0.71073 & 0.71073 \\
\hline Crystal system & monoclinic & Monoclinic \\
\hline Space group & $P 2_{1} / n$ & $C 2 / c$ \\
\hline$a(\AA)$ & $13.8301(2)$ & $29.7994(16)$ \\
\hline$b(\AA)$ & $16.2359(2)$ & $10.4438(6)$ \\
\hline$c(\AA)$ & $18.6267(3)$ & $18.1018(11)$ \\
\hline$\beta\left(^{\circ}\right)$ & $94.075(2)$ & $98.745(6)$ \\
\hline$V\left(\AA^{3}\right)$ & 4171.94(10) & $5568.1(6)$ \\
\hline$Z$ & 4 & 4 \\
\hline Density (calculated) $\left(\mathrm{g} \mathrm{cm}^{-3}\right)$ & 1.338 & 1.375 \\
\hline Absorption coefficient $\left(\mathrm{mm}^{-1}\right)$ & 0.644 & 0.739 \\
\hline$F(000)$ & 1760 & 2400 \\
\hline Crystal size (mm) & $0.38 \times 0.26 \times 0.18$ & $0.22 \times 0.21 \times 0.08$ \\
\hline Colour, habit & colorless, prism & light green, plate \\
\hline \multirow[t]{2}{*}{$\theta$ range for data collection $\left({ }^{\circ}\right)$} & 3.07 to 30.29 & 3.15 to 30.39 \\
\hline & $-18 \leq h \leq 12$ & $-36 \leq h \leq 21$ \\
\hline \multirow[t]{2}{*}{ Index ranges } & $-22 \leq k \leq 22$ & $-12 \leq k \leq 12$ \\
\hline & $-25 \leq l \leq 25$ & $-20 \leq l \leq 21$ \\
\hline Reflections collected/unique $\left(R_{\text {int }}\right)$ & $36095 / 11013(0.0304)$ & $18454 / 5154(0.0790)$ \\
\hline Observed reflections $[I>2 \sigma(I)]$ & 7850 & 2906 \\
\hline Data/restraints/parameters & $11013 / 2 / 542$ & $5154 / 0 / 363$ \\
\hline Goodness-of-fit on $F^{2}$ & 0.962 & 0.805 \\
\hline Final $R_{1}{ }^{\mathrm{a}}, w R_{2}{ }^{\mathrm{b}}[I>2 \sigma(I)]$ & $0.0324,0.0788$ & $0.0392,0.0591$ \\
\hline Mean and max shift/error & 0.000 and 0.002 & 0.000 and 0.001 \\
\hline Largest diff. peak and hole $\left(\mathrm{e} \AA^{-3}\right)$ & 0.503 and -0.457 & $-0.259 / 0.666$ \\
\hline
\end{tabular}

${ }^{\mathrm{a}} R_{1}=\Sigma|| F_{o}|-| F_{c}|| / \Sigma\left|F_{o}\right|$.

$\mathrm{b}_{w R_{2}}=\left\{\Sigma w\left(F_{\mathrm{o}}^{2}-F_{\mathrm{c}}^{2}\right)^{2} / \Sigma w\left(F_{\mathrm{o}}^{2}\right)^{2}\right\}^{1 / 2}$.

\section{Results and Discussion}

3.1. Synthetic Comments and IR Spectra. The reactions that led to complexes $\mathbf{1}$ and $\mathbf{2}$ can be represented by the stoichiometric equation (1)

$$
\begin{aligned}
& \mathrm{Zn}\left(\mathrm{O}_{2} \mathrm{CPh}\right)_{2} \cdot 2 \mathrm{H}_{2} \mathrm{O}+2 \mathrm{~L} \underset{150^{\circ} \mathrm{C}, \mathrm{P}}{\stackrel{\mathrm{MeOH}}{\longrightarrow}} \\
& {\left[\mathrm{Zn}\left(\mathrm{O}_{2} \mathrm{CPh}\right)_{2}(\mathrm{~L})_{2}\right]+2 \mathrm{H}_{2} \mathrm{O}} \\
& 2 \mathrm{Ni}\left(\mathrm{O}_{2} \mathrm{CPh}\right)_{2} \cdot 2 \mathrm{H}_{2} \mathrm{O}+2 \mathrm{~L} \stackrel{\mathrm{MeCN} / \mathrm{CH}_{2} \mathrm{Cl}_{2}}{\longrightarrow} \\
& \mathrm{T} \\
& {\left[\mathrm{Ni}_{2}\left(\mathrm{O}_{2} \mathrm{CPh}\right)_{4}(\mathrm{~L})_{2}\right]+4 \mathrm{H}_{2} \mathrm{O}} \\
& 2
\end{aligned}
$$

Two features of the reactions represented by (1) deserve brief comments. First, complex 1 could be crystallized [in the form of the bis(methanol) solvate] only under solvothermal conditions. Solvothermal techniques [23] allow the application of high temperatures to reactions in relatively low boiling solvents and are an excellent method for the preparation of pure, crystalline products. Second, despite the excess of the ligand $\left(\mathrm{L}: \mathrm{Ni}^{\mathrm{II}}=2.5\right)$, only the dinuclear $1: 1$ complex 2 could be prepared. The steric bulk of both $\mathrm{PhCO}_{2}{ }^{-}$and $\mathrm{L}$ seems to disfavor the isolation of a sixcoordinate $\left[\mathrm{Ni}\left(\mathrm{O}_{2} \mathrm{CPh}\right)_{2}(\mathrm{~L})_{2}\right]$ molecule with chelating benzoato ligands. The preparation of the 5-coordinate dinuclear complex 2 can be partly attributed to the small tendency of $\mathrm{Ni}^{\mathrm{II}}$ to form tetrahedral species.

The IR bands of L [13] do not shift significantly in the spectra of 1 and 2 . The $v_{\text {as }}\left(\mathrm{CO}_{2}\right)$ band is difficult to assign in the spectra due to the appearance of various stretching vibration and the $\delta_{\text {as }}\left(\mathrm{CH}_{3}\right)$ mode in the 1630$1420 \mathrm{~cm}^{-1}$ region; thus, the application of the spectroscopic criterion of Deacon and Phillips [24] seems impossible [25]. The bands at 1366 and $1402 \mathrm{~cm}^{-1}$ in the spectra of 1 and 2, respectively, can safely be assigned to the symmetric carboxylate stretching mode, $v_{\mathrm{s}}\left(\mathrm{CO}_{2}\right)$, of the benzoato ligands [24]. 


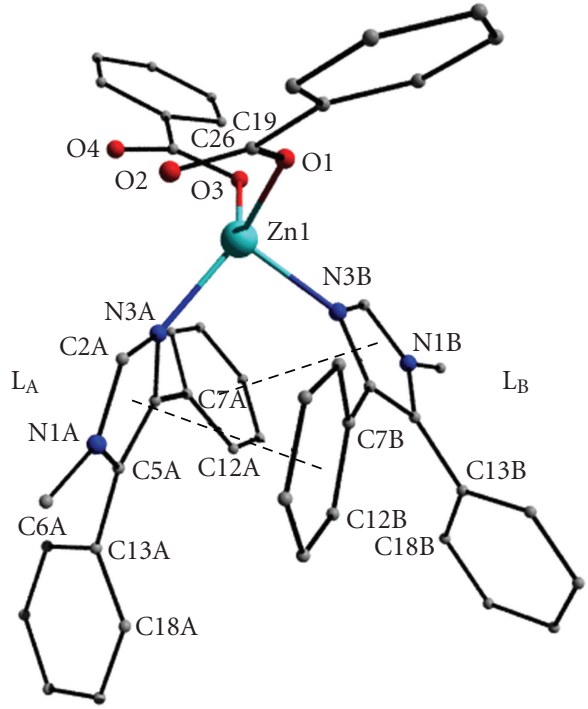

Figure 1: A partially labeled plot of complex $1 \cdot 2 \mathrm{MeOH}$. The methanol molecules and the hydrogen atoms have been omitted for clarity. The intramolecular $\pi-\pi$ interactions between the two ligands $\mathrm{L}_{\mathrm{A}}$ and $\mathrm{L}_{\mathrm{B}}$ are shown with dashed lines. Ring numeration: A1: N1A-C2A-N3A-C4A-C5A; A2: C7A to C12A; A3: C13A to C18A; B1: N1B-C2B-N3B-C4B-C5B; B2: C7B to C12B, B3: C13B to $\mathrm{C} 18 \mathrm{~B}$.

3.2. Description of the Structures. The molecular structures of complexes $\mathbf{1} \cdot 2 \mathrm{MeOH}$ and $\mathbf{2} \cdot 2 \mathrm{MeCN}$ are shown in Figures 1 and 2, respectively, selected bond lengths, angles, and torsion angles are listed in Table 2. To facilitate comparison, both compounds have the same (where applicable) atom, ring, and ligand numbering (ligand $\mathrm{L}_{\mathrm{A}}$ : rings $\mathrm{A} 1, \mathrm{~A} 2$ and $\mathrm{A} 3$; ligand $\mathrm{L}_{\mathrm{B}}$ : rings $\mathrm{B} 1, \mathrm{~B} 2$ and $\mathrm{B} 3$; see Figure 1 ).

Complex $1 \cdot 2 \mathrm{MeOH}$ consists of neutral mononuclear $\left[\mathrm{Zn}\left(\mathrm{O}_{2} \mathrm{CPh}\right)_{2}(\mathrm{~L})_{2}\right]$ molecules and methanol molecules in the lattice in a $1: 2$ ratio; it crystallizes in the monoclinic space group $P 2_{1} / n$. The two benzoate ions coordinate to $\mathrm{Zn}(\mathrm{II})$ in a monodentate fashion; this results in a distorted tetrahedral environment about the $\mathrm{Zn}$ (II) centre comprising two benzoate oxygen atoms and two pyridinetype, imidazole nitrogen donor atoms from the two 1methyl-4,5-diphenylimidazole (L) molecules. Both benzoate species are planar. The $\mathrm{L}_{A}$ and $\mathrm{L}_{\mathrm{B}}$ ligands of the complex are "antiparallel" with their methyl groups pointing at opposite directions. The overall conformation of $\mathrm{L}_{\mathrm{A}}$ and $\mathrm{L}_{\mathrm{B}}$ is similar. The angle between the mean planes of the phenyl rings $\mathrm{A} 2 / \mathrm{A} 3$ and $\mathrm{B} 2 / \mathrm{B} 3$ is $70.5(1)^{\circ}$ and $67.0(1)^{\circ}$, respectively. Moreover, the imidazole ring A1 is facing the phenyl ring $\mathrm{B} 2\left[10.5(1)^{\circ}\right]$ and, similarly, the imidazole ring $\mathrm{B} 1$ is facing the phenyl ring $\mathrm{A} 2\left[4.9(1)^{\circ}\right]$ forming weak intramolecular interligand $\pi-\pi$ interactions among those pairs of rings (Table 3 ). It seems that steric effects and the distorted tetrahedral geometry of the $\mathrm{Zn}(\mathrm{II})$ centre $\left[\mathrm{N} 3 \mathrm{~A}-\mathrm{Zn} 1-\mathrm{N} 3 \mathrm{~B}=96.6(1)^{\circ}\right]$ facilitate those $\pi-\pi$ interactions. Similar intramolecular $\pi-\pi$ interactions between $\mathrm{L}_{\mathrm{A}}$ and $\mathrm{L}_{\mathrm{B}}$ have also been reported for $\mathrm{Pd}^{\mathrm{II}}[14]$, and $\mathrm{Co}^{\mathrm{II}}$ and $\mathrm{Ni}^{\mathrm{II}}$ [12] complexes with $\mathrm{L}$, in a series of analogous complexes of
TAble 2: Selected interatomic distances $(\AA)$, angles and torsion angles $\left({ }^{\circ}\right)$ for $\mathbf{1} \cdot 2 \mathrm{MeOH}$ and $\mathbf{2} \cdot 2 \mathrm{MeCN}$.

\begin{tabular}{|c|c|c|}
\hline Compound & $1 \cdot 2 \mathrm{MeOH}$ & $2 \cdot 2 \mathrm{MeCN}$ \\
\hline $\mathrm{M}$ & $\mathrm{Zn}$ & $\mathrm{Ni}$ \\
\hline $\mathrm{M} \cdots \mathrm{M}^{\mathrm{i}}$ & & $2.734(1)$ \\
\hline $\mathrm{M}-\mathrm{N} 3 \mathrm{~A}$ & $2.007(1)$ & $2.017(2)$ \\
\hline $\mathrm{M}-\mathrm{N} 3 \mathrm{~B}$ & $2.065(1)$ & \\
\hline $\mathrm{M}-\mathrm{O} 1$ & $1.947(1)$ & $2.015(2)$ \\
\hline $\mathrm{M}-\mathrm{O} 3$ & $1.950(1)$ & $2.039(2)$ \\
\hline $\mathrm{M}-\mathrm{O} 2$ & & $2.008(2)$ \\
\hline $\mathrm{M}-\mathrm{O} 4$ & & $2.026(2)$ \\
\hline N3A-M-N3B & $96.6(1)$ & \\
\hline N3A-M-O1 & $123.4(1)$ & $91.9(1)$ \\
\hline $\mathrm{N} 3 \mathrm{~A}-\mathrm{M}-\mathrm{O} 2$ & & $103.3(1)$ \\
\hline N3A-M-O3 & $123.9(1)$ & $98.2(1)$ \\
\hline N3A-M-O4 & & $96.7(1)$ \\
\hline N3B-M-O1 & $103.0(1)$ & \\
\hline N3B-M-O3 & $97.2(1)$ & \\
\hline $\mathrm{O} 1-\mathrm{M}-\mathrm{O} 3$ & $105.7(4)$ & $88.0(1)$ \\
\hline $\mathrm{O} 1-\mathrm{M}-\mathrm{O} 4$ & & $89.9(1)$ \\
\hline $\mathrm{O} 2-\mathrm{M}-\mathrm{O} 3$ & & $90.7(1)$ \\
\hline $\mathrm{O} 2-\mathrm{M}-\mathrm{O} 4$ & & $87.4(1)$ \\
\hline C19-M-C26 & $112.46(4)$ & \\
\hline $\mathrm{A} 2-\mathrm{A} 3^{*}$ & $70.5(1)$ & $61.9(1)$ \\
\hline $\mathrm{B} 2-\mathrm{B} 3 *$ & $67.0(1)$ & \\
\hline $\mathrm{C} 4 \mathrm{~A}-\mathrm{C} 5 \mathrm{~A}-\mathrm{C} 13 \mathrm{~A}-\mathrm{C} 14 \mathrm{~A}$ & $-57.8(2)$ & $-53.0(4)$ \\
\hline C4B-C5B-C13B-C14B & $-56.8(2)$ & \\
\hline $\mathrm{C} 5 \mathrm{~A}-\mathrm{C} 4 \mathrm{~A}-\mathrm{C} 7 \mathrm{~A}-\mathrm{C} 12 \mathrm{~A}$ & $-46.6(2)$ & $-40.5(4)$ \\
\hline $\mathrm{C} 5 \mathrm{~B}-\mathrm{C} 4 \mathrm{~B}-\mathrm{C} 7 \mathrm{~B}-\mathrm{C} 12 \mathrm{~B}$ & $-37.3(2)$ & \\
\hline
\end{tabular}

*Angle between the mean-planes of the named phenyl rings (see Figure 1). Symmetry codes: (i) $1 / 2-x, 1 / 2-y, 1-z$.

other divalent metals with $\mathrm{L}[26]$ as well as in $\mathrm{Cu}^{\mathrm{II}}$ and $\mathrm{Zn}^{\mathrm{II}}$

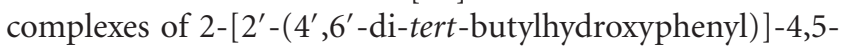
diphenylimidazole $[27,28]$. This structural feature records a preferable mode of packing between adjacent ligands bearing the 4,5-diphenylimidazole moiety and provides stabilization within the complex; it also supports the suitability of the ligand L as a crystal engineering tool, namely, its effect, through the $\pi-\pi$ interactions, in the assembly and packing of complexes in inorganic supramolecular chemistry $[29,30]$. The length of the $\mathrm{C}-\mathrm{C}$ and $\mathrm{C}-\mathrm{N}$ bonds of the imidazole groups, for both $1 \cdot 2 \mathrm{MeOH}$ and $2 \cdot 2 \mathrm{MeCN}$, are as expected in [31]; the $\mathrm{Zn}-\mathrm{N}$ and $\mathrm{Zn}-\mathrm{O}$ bond lengths are normal for this kind of compound.

One of the methanol molecules (O5) in the lattice is involved in two strong intramolecular $\mathrm{O}-\mathrm{H} \cdots \mathrm{O}$ hydrogen bonds to the noncoordinated oxygen atom $(\mathrm{O} 2)$ of one benzoate and to the second methanol (O6) molecule. There is also a weak $\mathrm{C}-\mathrm{H} \cdots \mathrm{O}$ (benzoate) interaction involving the noncoordinated oxygen atom $(\mathrm{O} 4)$ of the other benzoato ligand. The packing of the molecules in the crystal lattice proceeds through normal van der Waals contacts and some weak intermolecular $\mathrm{C}-\mathrm{H} \cdots \mathrm{O}$ interactions contributing to the supramolecular assembly of the structure (Table 4). 


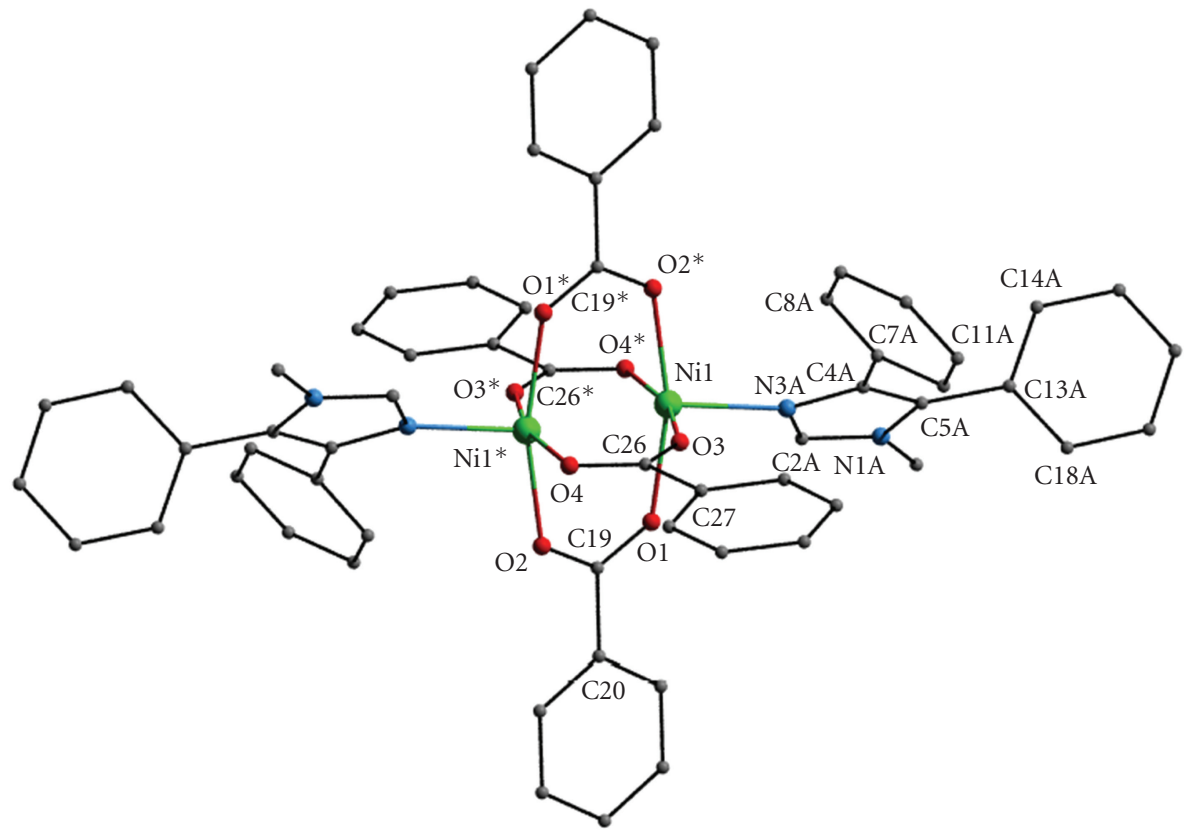

Figure 2: A partially labeled plot of the dinuclear complex $2 \cdot 2 \mathrm{MeCN}$. The acetonitrile molecules and the hydrogen atoms have been omitted for clarity. Asterisks are used for symmetry related $(1 / 2-x, 1 / 2-y, 1-z)$ atoms.

Table 3: Geometrical details $\left(\AA,{ }^{\circ}\right)$ of the intramolecular $\pi-\pi$ interactions between $\mathrm{L}_{\mathrm{A}}$ and $\mathrm{L}_{\mathrm{B}}$ ligands for complex $\mathbf{1} \cdot 2 \mathrm{MeOH}$.

\begin{tabular}{lcc}
\hline & Rings & Distance/Angle \\
\hline Distance between ring & $\mathrm{A} 1-\mathrm{B} 2$ & $3.547(1)$ \\
centroids & $\mathrm{B} 1-\mathrm{A} 2$ & $3.622(1)$ \\
Perpendicular distance & $\mathrm{A} 1-\mathrm{B} 2$ & $3.437(1)$ \\
between ring planes & $\mathrm{B} 1-\mathrm{A} 2$ & $3.363(1)$ \\
& $\mathrm{A} 1-\mathrm{B} 2$ & $0.876(1)$ \\
Centroid offset & $\mathrm{B} 1-\mathrm{A} 2$ & $1.346(1)$ \\
Dihedral angle between & $\mathrm{A} 1-\mathrm{B} 2$ & $10.5(1)$ \\
ring mean-planes & $\mathrm{B} 1-\mathrm{A} 2$ & $4.9(1)$ \\
\hline
\end{tabular}

It is known that $\mathrm{C}-\mathrm{H} \cdots \mathrm{O}$ bonds could play a role in the organization of crystal packing, especially when classic hydrogen bonding is absent [32-35]. A view of the crystal packing of complex $\mathbf{1} \cdot 2 \mathrm{MeOH}$ is shown in Figure 3.

The dinuclear paddle-wheel type complex $2 \cdot 2 \mathrm{MeCN}$, $\left.\left[\mathrm{Ni}_{2}\left(\mathrm{O}_{2} \mathrm{CPh}\right)\right)_{4}(\mathrm{~L})_{2}\right] \cdot 2 \mathrm{MeCN}$, crystallizes in the monoclinic space group $C 2 / c$ with two solvate acetonitrile molecules. The asymmetric unit comprises half molecule of the complex and one acetonitrile molecule, and the structure is generated by inversion at the midpoint of the $\mathrm{Ni}$. . Ni distance. The four bidentate benzoate groups bridge the two $\mathrm{Ni}$ ions in a paddle-wheel arrangement about the $\mathrm{Ni} \cdot \cdots \mathrm{Ni}$ axis. Thus, each $\mathrm{Ni}^{\mathrm{II}}$ atom is penta-coordinated exhibiting a square pyramidal geometry with the apex occupied by the pyridine-type, imidazole nitrogen donor atom (N3A) of one monodentate 1-methyl-4,5-diphenylimidazole ligand.

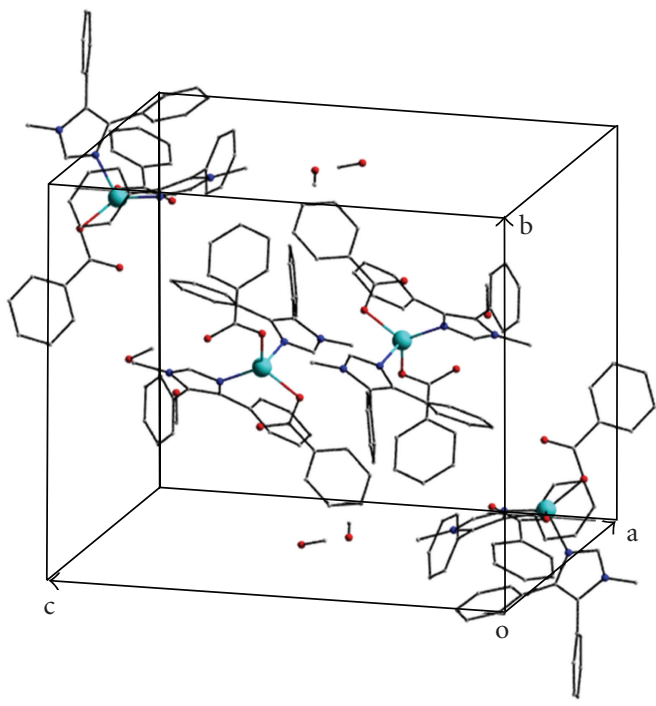

FIGURE 3: View of the crystal packing of complex 1.2MeOH. The hydrogen atoms have been omitted for clarity. Zn: turquoise; O: red; $\mathrm{N}$ : blue; C: grey.

The $\mathrm{Ni}$ to apical N3A atom distance is 2.017(2), the four Ni-O(benzoate) bond lengths range from 2.008(2) to $2.039(2) \AA$, and the $\mathrm{Ni} \cdot \cdots \mathrm{Ni}-\mathrm{N} 3 \mathrm{~A}$ angle is $160.8(1)^{\circ}$. The $\mathrm{Ni}$ atom lies $0.266(1) \AA$ out of the least-squares basal plane towards $\mathrm{N} 3 \mathrm{~A}$ atom. The $\mathrm{Ni} \cdot \cdots \mathrm{Ni}$ distance is 2.734(1) $\AA$, shorter than the maximum distance of $\sim 3.5 \AA$ that the tetracarboxylate paddle-wheel motif can accommodate for metal-metal separations. The acetonitrile molecule is linked 
TABLE 4: Hydrogen-bond geometries for $1 \cdot 2 \mathrm{MeOH}$ and $2 \cdot 2 \mathrm{MeCN}$ $\left(\AA,{ }^{\circ}\right)$.

\begin{tabular}{|c|c|c|c|c|}
\hline $\mathrm{D}-\mathrm{H} \cdots \mathrm{A}$ & $\mathrm{D}-\mathrm{H}$ & $\mathrm{H} \cdots \mathrm{A}$ & $\mathrm{D} \cdots \mathrm{A}$ & $\mathrm{D}-\mathrm{H} \cdots \mathrm{A}$ \\
\hline \multicolumn{5}{|l|}{ Complex $1 \cdot 2 \mathrm{MeOH}$} \\
\hline 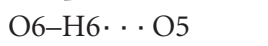 & $0.855(19)$ & $1.916(19)$ & $2.764(2)$ & $172(2)$ \\
\hline $\mathrm{O} 5-\mathrm{H} 5 \cdots \mathrm{O} 2^{\mathrm{i}}$ & $0.847(17)$ & $1.913(17)$ & $2.738(2)$ & $165(2)$ \\
\hline C8B-H8B $\cdots \mathrm{O} 1$ & 0.93 & 2.50 & $3.282(2)$ & 142 \\
\hline C6B-H6B3 $\cdots$ O $1^{\mathrm{ii}}$ & 0.96 & 2.432 & $3.370(2)$ & 166 \\
\hline C33-H33B $\cdots \mathrm{O}^{\mathrm{i}}$ & 0.96 & 2.52 & $3.423(2)$ & 157 \\
\hline \multicolumn{5}{|l|}{ Complex $2 \cdot 2 \mathrm{MeCN}$} \\
\hline C8A-H8A $\cdots$ O 2 & 0.93 & 2.30 & $3.151(3)$ & 152 \\
\hline $\mathrm{C} 34-\mathrm{H} 34 \mathrm{C} \cdots \mathrm{O} 1^{\mathrm{iii}}$ & 0.96 & 2.50 & $3.371(4)$ & 151 \\
\hline
\end{tabular}

Symmetry codes: (i) $-1+x,-1+y, z$; (ii) $2-x, 2-y,-z$; (iii) $x, 1+y, z$.

to the complex via a weak $\mathrm{C}-\mathrm{H} \cdots \mathrm{O}$ (benzoate) interaction (Table 4). The bridged dinuclear structure $\mathrm{M}_{2}\left(\eta^{1}: \eta^{1}: \mu\right.$ $\left.\mathrm{O}_{2} \mathrm{CR}\right)_{4}$ (ligand) $)_{2}$, first documented in 1953 for copper(II) acetate monohydrate, is ubiquitous in modern coordination chemistry [36]. It is found not only for carboxylates of many transition elements, but also for dimers containing a wide variety of other triatomic bridging ligands. This structural type is associated with a spectrum of metal-metal interactions ranging from no interactions, weak or moderate spin-pairing in the copper(II) carboxylates, various orders of metal-metal bonding, to the "super-short" metal-metal bonds $(\mathrm{M}-\mathrm{M}<2 \AA)$. The axial groups are normally monodentate ligands but they may represent interdimer association into a polymeric structure or may be absent.

It should be mentioned that attempts were made to prepare metal(II)-benzoate complexes with the 1-methyl4,5-diphenylimidazole ligand for the divalent metals Co, $\mathrm{Ni}, \mathrm{Cu}$, and $\mathrm{Zn}$, varying the factors that could affect the self-assembly of supramolecular architectures (such as the solvents used, temperature, counter-ion, the ligand-to-metal ratio, method of preparation, etc.). However, our trials yielded only the present two crystalline materials. It seems that the capability of the benzoate group to adopt different ligation modes plays, at least in the present case, a role in the formation of different coordination structural types.

\section{Conclusions}

The use of 1-methyl-4,5-diphenylimidazole ligand (L) in reactions with $\mathrm{Zn}\left(\mathrm{O}_{2} \mathrm{CPh}\right)_{2} \cdot 2 \mathrm{H}_{2} \mathrm{O}$ and $\mathrm{Ni}\left(\mathrm{O}_{2} \mathrm{CPh}\right)_{2}$. $2 \mathrm{H}_{2} \mathrm{O}$ has yielded the mononuclear $\left[\mathrm{Zn}\left(\mathrm{O}_{2} \mathrm{CPh}\right)_{2}(\mathrm{~L})_{2}\right]$. $2 \mathrm{MeOH}$ complex $(\mathbf{1} \cdot 2 \mathrm{MeOH})$ and the dinuclear $\left.\left[\mathrm{Ni}_{2}\left(\mathrm{O}_{2} \mathrm{CPh}\right)\right)_{4}(\mathrm{~L})_{2}\right] \cdot 2 \mathrm{MeCN} \quad(\mathbf{2} \cdot 2 \mathrm{MeCN})$ compound. The different benzoate binding mode to the metals used, monodentate in the former and bidentate in the latter complex, has led to two different coordination geometries for the two divalent metals. The characteristic structural pattern [12] of the intramolecular $\pi-\pi$ interactions between aromatic rings of adjacent 4,5-diphenylimidazole moieties of the two L ligands is also present in the structure of $1 \cdot 2 \mathrm{MeOH}$ and contributes to the stability and rigidity of the structure.

\section{Acknowledgment}

This paper was supported by the Research Committee of the University of Patras, Greece (K. Caratheodory program, Grant no C.585 to Vassilios Nastopoulos).

\section{References}

[1] P. J. Steel, "Aromatic nitrogen heterocycles as bridging ligands: a survey," Coordination Chemistry Reviews, vol. 106, pp. 227265, 1990.

[2] E. C. Constable, Metals and Ligand Reactivity: An Introduction to the Organic Chemistry of Metal Complexes, Verlag Chemie, Weinheim, Germany, 1996.

[3] H.-B. Kraatz and N. Metzler-Nolte, Concepts and Models in Bioinorganic Chemistry, Wiley-VCH, Weinheim, Germany, 2006.

[4] S. J. Lippard and J. M. Berg, Principles of Bioinorganic Chemistry, University Science Books, Mill Valley, Calif, USA, 1994.

[5] J. W. Steed and J. L. Atwood, Supramolecular Chemistry, Wiley, Chichester, UK, 2000.

[6] J.-M. Lehn, "Supramolecular chemistry," Science, vol. 260, no. 5115, pp. 1762-1763, 1993.

[7] J.-M. Lehn, Supramolecular Chemistry. Concepts and Perspectives, Wiley-VCH, Weinheim, Germany, 1995.

[8] A. I. Kitaigorodsky, Kitaigorodsky, Molecular Crystals and Molecules, Academic Press, New York, NY, USA, 1973.

[9] J.-M. Lehn, "Perspectives in supramolecular chemistryfrom molecular recognition towards molecular information processing and self-organization," Angewandte Chemie. International Edition, vol. 29, no. 11, pp. 1304-1319, 1990.

[10] P. S. Corbin, S. C. Zimmerman, P. A. Thiessen, N. A. Hawryluk, and T. J. Murray, "Complexation-induced unfolding of heterocyclic ureas. Simple foldamers equilibrate with multiply hydrogen-bonded sheetlike structures," Journal of the American Chemical Society, vol. 123, no. 43, pp. 10475-10488, 2001.

[11] C. B. Aakeröy and K. R. Seddon, "The hydrogen bond and crystal engineering," Chemical Society Reviews, vol. 22, no. 6, pp. 397-407, 1993.

[12] K. A. Kounavi, C. Papatriantafyllopoulou, A. J. Tasiopoulos, S. P. Perlepes, and V. Nastopoulos, "The supramolecular chemistry of metal complexes with heavily substituted imidazoles as ligands: cobalt(II) and zinc(II) complexes of 1-methyl-4,5diphenylimidazole," Polyhedron, vol. 28, no. 15, pp. 33493355, 2009.

[13] C. P. Raptopoulou, S. Paschalidou, A. A. Pantazaki et al., "Bis(acetato)bis(1-methyl-4,5-diphenylimidazole)copper(II): preparation, characterization, crystal structure, DNA strand breakage and cytogenetic effect," Journal of Inorganic Biochemistry, vol. 71, no. 1-2, pp. 15-27, 1998.

[14] A. Hadzovic and D. Song, "Synthesis, characterization, and reactivity of a versatile dinuclear palladium $\beta$-diiminate complex," Organometallics, vol. 27, no. 6, pp. 1290-1298, 2008.

[15] J. McMaster, R. L. Beddoes, D. Collison, D. R. Eardley, M. Helliwell, and C. D. Garner, "A bis(diimidazole)copper complex possessing a reversible $\mathrm{Cu}^{\mathrm{II}} / \mathrm{Cu}^{\mathrm{I}}$ couple with a high redox potential," Chemistry-A European Journal, vol. 2, no. 6, pp. 685-693, 1996.

[16] CrysAlis CCD and CrysAlis RED, Programs for Data Collection, Cell Refinement and Data Reduction, Version 1.171.32.15, Oxford Diffraction Ltd, Oxford, UK, 2008. 
[17] A. Altomare, G. Cascarano, C. Giacovazzo, et al., "SIR92-a program for automatic solution of crystal structures by direct methods," Journal of Applied Crystallography, vol. 27, p. 435, 1994.

[18] G. M. Sheldrick, SHELXL-97, A program for the refinement of crystal structures from diffraction data, University of Göttingen, Germany, 1997.

[19] L. J. Farrugia, "WinGX suite for small-molecule single-crystal crystallography," Journal of Applied Crystallography, vol. 32, no. 4, pp. 837-838, 1999.

[20] A. L. Spek, PLATON. A multipurpose crystallographic tool, Utrecht University, The Netherlands, 2003.

[21] C. F. Macrae, P. R. Edgington, P. McCabe et al., "Mercury: visualization and analysis of crystal structures," Journal of Applied Crystallography, vol. 39, no. 3, pp. 453-457, 2006.

[22] K. Brandenburg, DIAMOND, Program for crystal and molecular structure visualization, Release 3.1f, Crystal Impact GbR, Bonn, Germany, 2008.

[23] E. K. Brechin, "Using tripodal alcohols to build high-spin molecules and single-molecule magnets," Chemical Communications, no. 41, pp. 5141-5153, 2005.

[24] G. B. Deacon and R. J. Phillips, "Relationships between the carbon-oxygen stretching frequencies of carboxylato complexes and the type of carboxylate coordination," Coordination Chemistry Reviews, vol. 33, pp. 227-250, 1980.

[25] D. Martínez, M. Motevalli, and M. Watkinson, "Is there really a diagnostically useful relationship between the carbonoxygen stretching frequencies in metal carboxylate complexes and their coordination mode?" Dalton Transactions, vol. 39, no. 2, pp. 446-455, 2010.

[26] K. A. Kounavi, et al., unpublished results.

[27] L. Benisvy, A. J. Blake, D. Collison et al., "A phenoxyl radical complex of copper(II)," Chemical Communications, no. 18, pp. 1824-1825, 2001.

[28] L. Benisvy, A. J. Blake, D. Collison et al., "A phenol-imidazole pro-ligand that can exist as a phenoxyl radical, alone and when complexed to copper(II) and zinc(II)," Dalton Transactions, no. 10, pp. 1975-1985, 2003.

[29] I. Dance, Perspectives in Supramolecular Chemistry: The Crystal as a Supramolecular Entity, vol. 2, Wiley, Chichester, UK, 1995.

[30] C. B. Aakeröy, "Crystal engineering: strategies and architectures," Acta Crystallographica Section B, vol. 53, no. 4, pp. 569586, 1997.

[31] F. H. Allen, O. Kennard, D. G. Watson, L. Brammer, A. G. Orpen, and R. Taylor, "Tables of bond lengths determined by $\mathrm{x}$-ray and neutron diffraction. Part 1 . Bond lengths in organic compounds," Journal of the Chemical Society, Perkin Transactions 2, no. 12, pp. S1-S19, 1987.

[32] G. R. Desiraju, Crystal Engineering. The Design of Organic Solids, Elsevier, Amsterdam, The Netherlands, 1989.

[33] G. R. Desiraju, "The C-H ․ O hydrogen bond: structural implications and supramolecular design," Accounts of Chemical Research, vol. 29, no. 9, pp. 441-449, 1996.

[34] G. A. Jeffrey, An Introduction to Hydrogen Bonding, Oxford University Press, Oxford, UK, 1997.

[35] T. Steiner, "The hydrogen bond in the solid state," Angewandte Chemie. International Edition, vol. 41, no. 1, pp. 48-76, 2002.

[36] S. P. Perlepes, J. C. Huffman, and G. Christou, "Preparation and characterization of triply-bridged dinuclear copper(II) complexes containing the $\left[\mathrm{Cu}_{2}(\mu-\mathrm{OH})(\mu-\mathrm{X})(\mu-\mathrm{OAc})\right]^{+}$ core $(\mathrm{X}=\mathrm{Cl}, \mathrm{Br})$, and the crystal structure of $\left[\mathrm{Cu}_{2}(\mathrm{OH}) \mathrm{Cl}(\mathrm{OAc})(\mathrm{bpy})_{2}\right]\left(\mathrm{ClO}_{4}\right) \cdot \mathrm{H}_{2} \mathrm{O}$," Polyhedron, vol. 10, no. 19 , pp. 2301-2308, 1991. 


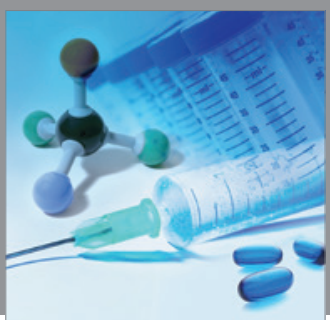

International Journal of

Medicinal Chemistry

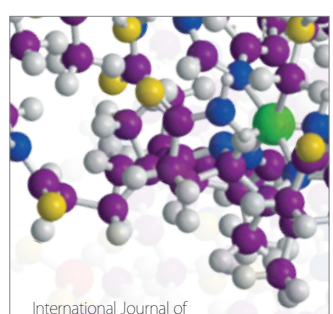

Carbohydrate Chemistry

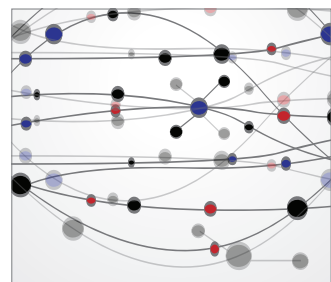

The Scientific World Journal
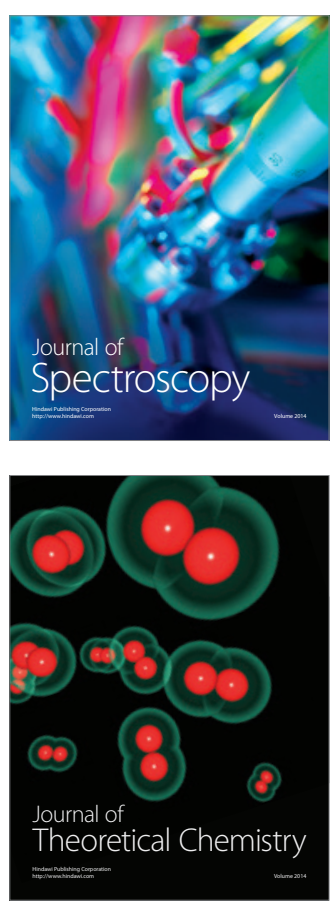
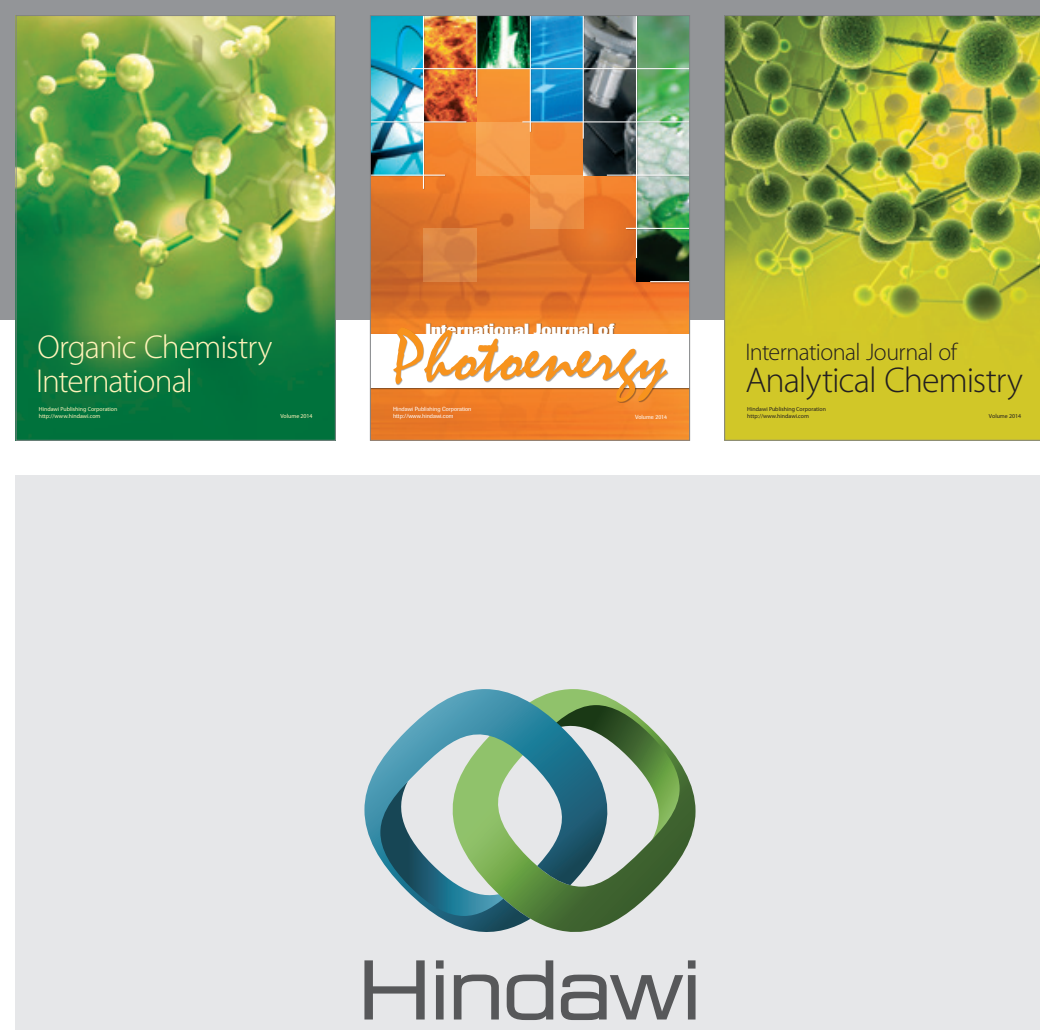

Submit your manuscripts at

http://www.hindawi.com
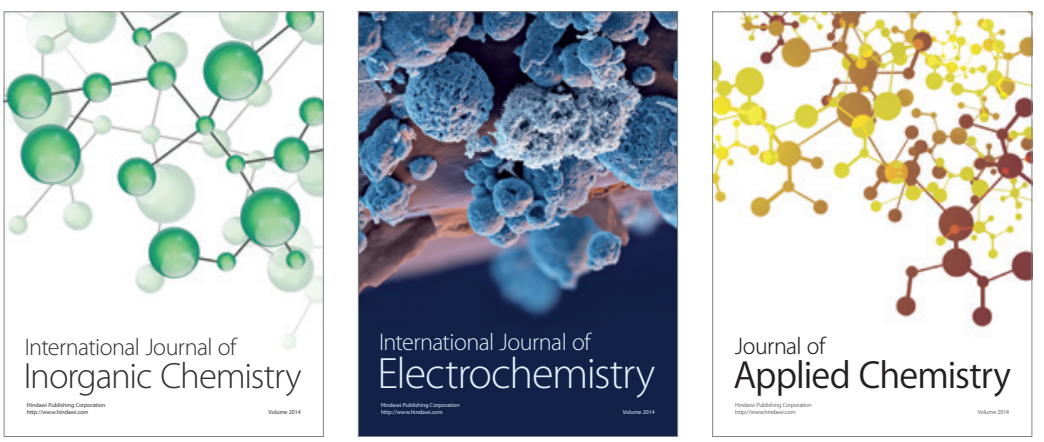

Journal of

Applied Chemistry
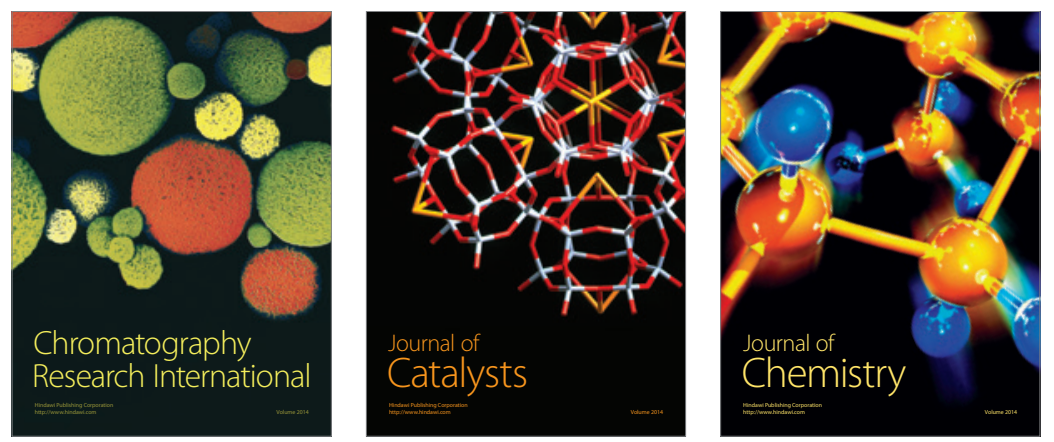
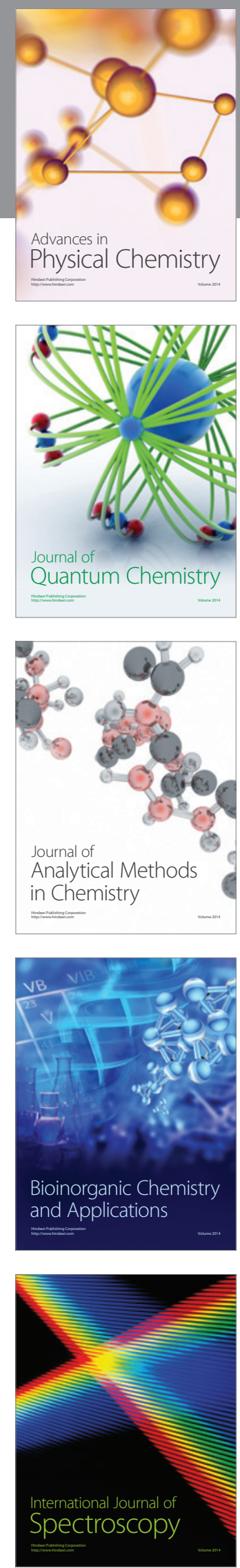